\title{
I. ИССЛЕДОВАНИЯ
}

ИНТЕНЦИОНАЛЬНОСТЬ: АМЕРИКАНСКАЯ ТОЧКА ЗРЕНИЯ

\section{СЕРГЕЙ НИКОНЕНКО}

Доктор философских наук, профессор.

Санкт-Петербургский государственный университет, Институт философии. 199034 Санкт-Петербург, Россия.

E-mail: serg_nikonenko@rambler.ru

Статья представляет трактовку понятия «интенциональность» в феноменологически ориентированной аналитической философии сознания США в сопоставлении с феноменологией Э. Гуссерля. Дается систематический очерк развития феноменологических тенденций в американской аналитической философии, приводятся взгляды основных представителей. Главной концепцией интенциональности в США считается теория Дж. Серля; она подробно исследуется в статье. Также исследуются взгляды на природу интенциональности современных философов: Э. Томпсона, Д. В. Смита и др. В основном, статья написана на основе источников, не переведенных на русский язык. Серль понимает интенциональность в духе натуралистической философии сознания, трактуя ее как естественное качество человеческого сознания. Он отходит от лингвистической трактовки сознания, понимая интенциональность с точки зрения человеческой формы реализма. В центре интенциональности Серль ставит теорию аспектуальности, в основе которой лежит допущение неэлиминируемой субъективности ментального акта и онтологии от первого лица. Серль также приходит к теории коллективной интенциональности, которая выступает версией решения проблемы интерсубъективности. При рассмотрении теорий Томпсона и Смита отмечается, что проблема интенциональности обсуждается на уровне синтетического подхода, когда в равной мере представлены дискуссии в области философии сознания, нейрофизиологии и феноменологии Гуссерля. Смит предлагает контекстуальную теорию интенциональности, согласно которой каждый интенциональный акт должен рассматриваться не в атомарной форме, а в виде элемента целостного контекста всех интенциональных актов этого сознания. В статье проводится троякое сопоставление философии Гуссерля с идеями американских феноменологически ориентированных философов с целью выявления общности и различий (в отношении понятий «опыт», «интенциональность» и «интерсубъективность»). В качестве основных сходств установлена общность в трактовке опыта: отнесение опыта к внутренней сфере сознания, критика сенсуализма и экстернализма, неотделимость опыта от инту-

(C) SERGEI NIKONENKO, 2017 
итивно-созерцательной перспективности. Относительно интенциональности установлена общность в понимании сущности этого понятия, а также неэлиминируемости интенциональности. Относительно интерсубъективности показано, что Серль в учении о коллективной интенциональности развивает учение Гуссерля об интерсубъективно-трансцендентальной социальности. Вместе с тем, установлено, что Серль и другие американские аналитики имеют расхождения с Гуссерлем. Так, Серль, понимая интенциональность не только в феноменологическом, но и прагматистском ключе, подчеркивает реалистический характер интенциональности, ее преимущественно эмпирический характер, и выступает критиком трансцендентального учения о сущности чистого Я. Однако установленные различия, тем не менее, не препятствуют позитивному диалогу и сближению позиций между феноменологически ориентированной аналитической философией и европейской феноменологией, наличию существенных сходств и совпадений в решении проблем сознания, опыта, интенциональности, понимания и т.д.

Ключевые слова: Интенциональность, феноменология, аналитическая философия, эпистемология, сознание, субъект, опыт, интерсубъективность.

\section{INTENTIONALITY: AN AMERICAN POINT OF VIEW}

\section{SERGEI NIKONENKO}

DSc in Philosophy, Professor.

St. Petersburg State University, Institute of Philosophy. 199034 Saint-Petersburg, Russia.

E-mail: serg_nikonenko@rambler.ru

The matter of the article is to give an outline of American theories of intentionality and to compare it with E. Husserl's phenomenology. It is one of the first Russian systematic studies of American theories on intentionality that is represented here. It is John Searle's philosophy that is the main American theory of intentionality. Some other thinkers (R. Chisholm, J. Findlay, N. Rescher, E. Thompson, D. W. Smith, etc.) are studied here too. Searle treats intentionality as a natural quality of consciousness. He forbids the linguistic approach; intentionality is understood from the point of view of humanistic (internal) realism. Intentionality is successive when the subject is satisfied by his acquaintance with the object. The main feature of intentionality is aspectuality that has the subject of not eliminated subjectivity of any conscious act and the first person ontology. Searle proposes the collective intentionality that is analogous to phenomenological intersubjectivity. E. Thompson proposes the synthetic theory of intentionality that unites phenomenology, philosophy of consciousness and neural science. D. W. Smith proposes the theory of intentional context. He rejects the study of atomistic intentional acts. Husserl's and Searle's theories of phenomenology may be united in several main points: 1 . Experience is an internal process; 2 . Experience cannot be separated of aspectuality; 3 . Intentionality cannot be eliminated in any conscious act; 4 . The other mind can be considered only from internal point of view; 5 . There is collective intentionality of mankind. There are several distinctions between Husserl and Searle: 1. Searle is a realist on intentionality, Husserl puts on an idealistic concept of it; 2 . Searle considers intentionality from empirical point of view, not from the rationalist one; 3 . Searle is an adept of skepticism about self, he rejects transcendental concept of cogito. But irrespective of distinctions there is convergence of analytical and phenomenological views in contemporary philosophy of consciousness.

Key words: Intentionality, phenomenology, analytical philosophy, epistemology, consciousness, subject, experience, intersubjectivity. 


\section{I. ВВЕДЕНИЕ. \\ ОБЩИЙ ОЧЕРК ИССЛЕДОВАНИЙ ФЕНОМЕНОЛОГИИ В АМЕРИКАНСКОЙ ФИЛОСОФИИ}

Интерес к феноменологической проблематике в США существует давно, и в основном все дискуссии ведутся вокруг проблемы интенциональности. Неофициальным началом теоретического рассмотрения интенциональности в США принято считать статью Р. М. Чизолма «Предложения об убеждении» (1955-1956) (Chisholm, 1955-1956, 125-148). Он попытался сформулировать логический критерий интенционального употребления языка, согласно которому физические феномены нуждаются для адекватного понимания в интенциональных предложениях. Тем самым, Чизолм сразу обозначил и сферу интересов философов в США, а именно: пересечение феноменологических и аналитических идей, которое наблюдается, прежде всего, в области эпистемологии и философии сознания. Чтобы у читателя не возникло путаницы, мы уточним, что все американские философы, о которых пойдет речь в данной статье, считали себя аналитическими философами; поэтому в контексте проблематики интенциональности понятия «американская философия» и «аналитическая философия» - практически синонимы.

До появления статьи Чизолма американская философия находилась под влиянием идей ранних аналитиков (особенно Б. Рассела), которые не приняли и подвергли критике феноменологические идеи Гуссерля, Хайдеггера, Мерло-Понти, Сартра и др. На это указывает А. Манстер, который пишет: «Гуссерль и другие пост-фрегеанские европейцы практически не читались в сороковые и пятидесятые годы» (Manster, 1975, 111). В этой связи, Чизолм и другие первые исследователи феноменологии (А. Шютц, Г. Гарфинкель, Дж. Финдлэй, А. Гурвич, Я. Хинтикка, У. В. О. Куайн и др.) «сломали лед» предвзятого отношения к Гуссерлю и другим феноменологам. Конечно, этого не могло бы произойти, если бы в самой аналитической философии не произошли существенные изменения, такие как укрепление позиций антиреализма и лингвистической философии, зарождение философии сознания, а также все более тесное сближение с «континентальной философией». Можно констатировать, что в 1970-е гг. в США складывается устойчивая традиция изучения и комментирования наследия Брентано, Мейнонга, Гуссерля, Мерло-Понти и других представителей немецкой и французской феноменологии (добавим, что американские исследования феноменологии ведутся в тесном союзе 
с философами Великобритании, Австралии, других англоязычных стран, а также Германии). Апофеозом внимания к феноменологии можно считать появление сборника «Феноменология и философское понимание» (Phenomenology and Philosophical Understanding, 1975), в котором представлены: А. Квинтон, Д. Карр, А. Айер, Р. Занер, Дж. Финдлэй, П. Гич, П. Рикер, А. Флю и др. Далеко не все статьи в этом сборнике посвящены собственно феноменологии, равно как и далеко не все авторы - представители аналитической философии. Однако присутствие в сборнике таких авторитетных философов, как Айер и Рикер, позволяет говорить не только о теоретическом изучении и комментировании континентальной феноменологии в США, но также о начале собственных, национальных изысканий в области феноменологической проблематики. Об этом, в частности, свидетельствует Н.В. Мотрошилова, которая впервые в советской истории философии отмечает наличие американских феноменологических исследований (Motroshilova, 1968, 5).

В 1970-1980-е гг. постепенно складывается круг авторов, которые теоретически исследуют феноменологические проблемы в критическом ключе. Это такие философы, как: Г. Шпигельберг, Ф. Дретске, Дж. Фодор, М. Фарбер, У. Селларс, Н. Решер, Э. Соса и др. Вокруг Университета Беркли складывается группа философов и ученых, которая получила название «Калифорнийская феноменология» (Д. Фоллесдал, Я. Хинтикка, Г. Дрейфус, Р. Макинтайр, И. Миллер, Д. Смит и др.). Наконец, в начале 1980-х гг. формируется концепция Дж. Серля, которая может считаться крупнейшей американской разработкой проблемы интенциональности.

В этом кратком историческом введении мы отметим еще одну тенденцию (которая лежит за пределами предмета статьи, но является существенной для общей картины), а именно: наличие встречного интереса к проблематике и категориям аналитической философии у представителей современной континентальной феноменологии, что позволяет говорить о взаимном сближении вышеупомянутых традиций. К примеру, Д. Захави употребляет категории «аналитического» происхождения, такие как «реализм» и «антиреализм», что отмечает А. Хахалова (Khakhalova, 2015, 315).

Вводный раздел мы завершим двумя замечаниями, проливающими свет на общую суть американской версии проблемы интенциональности. Во-первых, проблематика интенциональности неразрывно связана с эпистемологией. В этом смысле, американские авторы не «берут в скобки» сферу чувственности; а это ставит существенные барьеры на пути к принятию идей 
Гуссерля. Как пишет Дж. Финдлэй: «Никто, можно сказать, не сможет понять феноменологию Гуссерля, если он не постиг трансцендентальных, реалистических корней интенционализма Брентано, корней, которые Гуссерль несколько грубо “взял в скобки” в различных концепциях, но которые в этом смысле остались нетронутыми и невредимыми внутри данных скобок» (Findlay, 1975, 146). Во-вторых, мы хотим предпослать основной части статьи крайне осторожное предположение, которое заключается в том, что вряд ли конструктивно говорить о такой сущности, как «американская феноменология». Ведь само понятие «феноменология» никогда нельзя строго определить, как отмечает М. Мерло-Понти: «Что такое феноменология? Может показаться странным, что этот вопрос ставится спустя полвека после появления первых работ Гуссерля; тем не менее, он все еще далек от разрешения» (Merlo-Ponti, 1999, 5). Можно с уверенностью допустить лишь то, что есть такая сущность, как «американские феноменологически ориентированные теории интенциональности». Так или иначе, американские исследователи феноменологии по своей сути остаются аналитическими философами, хотя в своей «феноменологической ориентации» отступают от некоторых «стандартов» аналитической философии, удачно выраженных М. Даммитом, который пишет: «Фреге был отцом аналитической философии, Гуссерль - основателем феноменологической школы; это два радикально различных философских движения» (Dummett, 1994, 26).

На наш взгляд, исследования интенциональности Серля и других американских авторов представляют существенный интерес для феноменологии и являются влиятельной философской позицией, к которой нельзя не прислушаться. Поэтому выглядит оправданной и конструктивной идея детального сопоставления идей американских «феноменологов» и идей Гуссерля, которая предпринимается в настоящей работе. Для понимания современной феноменологии представляется актуальным установление сходств и различий между положениями Гуссерля и американских теоретиков интенциональности. В качестве главной задачи статьи необходимо установить решение следующего вопроса: в чем Серль и другие американские теоретики следуют Гуссерлю, а в чем расходятся с ним? Этот теоретический вопрос нам представляется гораздо более важным, нежели рассмотрение американской феноменологически ориентированной аналитической философии самой по себе или решение пресловутого вопроса о наличии собственной феноменологии в США. К тому же, проблема самостоятельности и оригинальности феноме- 
нологических исследований в США присутствует в философском самосознании самих американцев. Об этом красноречиво говорит американский историк феноменологии Г. Шпигельберг:

Однако несмотря на большое количество и разнообразие подобный предприятий, которые, казалось бы, вывели Соединенные Штаты в лидеры феноменологической науки, решающей проблемой остается то, насколько большая часть этих усилий являет собой образец оригинального и конкретного феноменологического исследования, а не вторичного материала или введения в проблему. (Shpigel'berg, 2002, 624)

Композиция статьи проста. Мы критически исследуем теорию интенциональности Дж. Серля, проведем обзор других важных американских теорий, после чего предпримем троякое сопоставление идей Гуссерля и американских теоретиков интенциональности. Следует особо оговорить, что, в случае необходимости мы будем привлекать идеи аналитических философов, которые не считали себя «феноменологически ориентированными» авторами, но оказались теоретически близки в некоторых своих положениях идеям Гуссерля. Это позволит лучше очертить «общее поле» проблематики, которая может считаться смежной для феноменологии и аналитической философии.

\section{II. КОНЦЕПЦИЯ ИНТЕНЦИОНАЛЬНОСТИ ДЖ. СЕРЛЯ: КРИТИЧЕСКИЙ АНАЛИЗ}

Философия Джона Серля уже довольно основательно исследована в нашей стране; однако его теория интенциональности по-прежнему остается «белым пятном», во многом по причине отсутствия русского перевода труда «Интенциональность. Очерк философии сознания» (Searle, 1983). В этой книге Серль отходит от ранних материалистических идей и переходит на позиции умеренного плюралистического реализма относительно сознания. В течение 34 лет, которые прошли после выхода этого труда, Серль постоянно исследовал проблематику интенциональности. Настоящий раздел - это попытка систематизации и критики взглядов Серля на природу интенциональности, представленных в четырех монографиях этого мыслителя.

Первоначальная форма теории интенциональности Серля разрабатывается в рамках более общей натуралистической теории сознания, суть которой состоит в том, что ментальные феномены биологически укоренены, но аномальны по своей сути и прямо не сводимы к «физическим» структурам. 
В «Интенциональности» Серль пишет: «Подход к интенциональности в рамках этой книги совершенно натуралистический. Я сужу об интенциональных состояниях, процессах и событиях как о части нашей биологической истории» (Searle, 1983, 160). Тем самым, интенциональные состояния - это признаки сознательной деятельности биологических организмов. Натурализм Серля контрастирует с феноменологией Гуссерля, который относит интенциональность к деятельности cogito, чистого Я. Серль стремится доказать, что интенциональность - это естественное качество, которое относится к человеческой природе, занимая свое место в ряду других природных феноменов. «Подлинная интенциональность есть феномен, который присущ людям и некоторым другим животным как часть их биологической природы» (Serl', 2002, 89), - считает Серль. Тем самым, эта теория сознательной деятельности базируется на натуралистическом допущении. Неслучайно Серль выводит теорию фона (Background), который выступает врожденной, биологической «основой» любого возможного ментального акта. В принципе, Серль вполне солидарен с точкой зрения аномального монизма Д. Дэвидсона, согласно которой все сознательные феномены имеют физическую основу, но не могут быть полностью редуцированы к ней.

Интенциональность привлекает внимание Серля как категория, способная пролить свет на уникальность и исключительность деятельности человеческого сознания. Под интенциональным состоянием сознания Серль понимает любое состояние $C$, относительно которого можно ответить на вопрос: «О чем С?». «Интенциональное состояние состоит из репрезентативного содержания, взятого определенным психологическим способом» (Searle, $1983,11)$, - так предельно обще Серль определяет интенциональность. Новизна подхода Серля в рамках аналитической философии заключается в том, что он отходит от принципа лингвистического идеализма, согласно которому вся деятельность сознания выражается в языке. «Я не думаю, что интенциональность является существенно и необходимо лингвистической» (Searle, 1983, 5), - утверждает философ. Контент акта сознания должен анализироваться, исключительно исходя из своего собственного содержания; его нельзя редуцировать к чему-либо вне его.

В этом отношении Серль начинает отходить от натуралистической теории сознания и рассматривать интенциональность с субстанциальной точки зрения, — как «внутреннее и неэлиминируемое» качество (Serl', 2002, 20). Серль так и не решает противоречия: что такое сознание - естественный феномен 
или рациональность, понимаемая с субстанциальной точки зрения? Можно проследить как в своей философской эволюции Серль от книги к книге становится все менее «натуралистическим» и все более «идеалистическим» теоретиком сознания, то есть движется к все более и более «чистому» пониманию сознания.

Интенциональность как направленность сознания по отношению к объекту может быть только сознательной по своей форме. «Хотя многие, а на самом деле большинство наших интенциональных состояний в любом случае бессознательны, тем не менее, для того, чтобы бессознательное интенциональное состояние было подлинно интенциональным состоянием, оно должно быть принципиально сводимым к сознательной форме» (Searle, 2002, 12), пишет Серль. Для понимания этой точки зрения следует, прежде всего, систематизировать учение Серля о тех состояниях психики, которые не являются интенциональными. Это такие состояния:

- Любые акты сознания, которые не имеют направленности на объект;

- Любые бессознательные состояния;

- Любые состояния сознания, которые не могут быть представлены рационально и в пропозициональной форме.

Если отбросить натуралистический фундамент и рассматривать серлевскую теорию интенциональности вне контекста аналитической философии сознания, то можно усмотреть тесную близость с феноменологическим пониманием интенциональности. Это процесс, акт сознательной деятельности. Серль понимает интенциональность как внесение субъективной точки зрения в изучаемый предмет, «гуманизацию», «очеловечивание» этого предмета. Тем самым, интенциональность трактуется в духе человеческой бормь реализма, предложенной в трудах У. Селларса, Н. Гудмена, Д. Дэвидсона, Х. Патнэма и самого Серля. Интенциональный взгляд на объект делает его «нашим», освоенным объектом, входящим в сферу того или иного интереса (будь он теоретическим или практическим). Для сравнения приведем суждение Гуссерля, который пишет об интенциональности так: «От самого же cogito неотделим имманентный ему “взгляд-на” объект, взгляд, который с другой стороны изливается из “Я”, так что никогда не может быть так, чтобы его не было» (Gusserl', 1999, 81). Для обоих мыслителей интенциональность - это сознательный акт, заключающийся в направленности на объект, способе «выхода» сознания к феномену. 
Здесь мы подходим к самой оригинальной части учения Серля об интенциональности - положению об аспектуальности (aspectuality) интенционального акта. Первое определение аспектуальности Серль дает в «Интенциональности», рассуждая по поводу «уткозайца» Витгенштейна графической фигуры, которая в одном положении воспринимается как голова утки, а в другом — как голова зайца (Vitgenshtein, 1994, 278). «Мы никогда не видим объект сам по себе; мы всегда видим его с точки зрения аспекта» (Searle, 1983, 52), - пишет Серль. При восприятии уткозайца, тем самым, наш взгляд определяется видением-как, предпосланной точкой зрения. Между Серлем и Витгенштейном можно провести существенное отличие. Витгенштейн полагает, что при восприятии уткозайца наиболее значим вопрос наименования, приписывания видимому образу лингвистической сущности с определенным значением. Серль же не придает определяющего значения языковым критериям. Аспектуальность - это до-лингвистическая структура, укорененная на уровне функционирования сознания. Серль трактует аспектуальность в духе последовательного юмизма и натурализма, определяя ее как естественную избирательность сознания. Любые сознательные акты - это всегда «чьи-то» акты, обладающие неэлиминируемой субъективностью, накладывающей свой отпечаток на воспринимаемую картину мира. «Обращать внимание на перспективный характер сознательного опыта - это хороший способ напомнить себе о том, что всякая интенциональность аспектуальна. Например, видение объекта с некоторой точки зрения есть видение в одних аспектах, но не других» (Serl', 2002, 131), - отмечает Серль. В аналитической эпистемологии и до Серля много писалось об активности, избирательности сознания. В частности, такой точки зрения на опыт придерживался А. Н. Уайтхед, который пишет: «Конкретное событие опыта есть некоторая активность, разлагаемая на способы функционирования, которые в совокупности образуют процесс его становления» (Uaitkhed, 1990, 576). Уайтхед определяет процесс «выхода» сознания к объекту как «схватывание» (conjecture). Дж. Остин предлагает категорию «знание-как» (knowing-how) для обозначения такого эмпирического знания, которое зависит от пресуппозиции. У. Селларс в своей критике «Мифа Данного» (Myth of the Given) стремится доказать, что теория чувственных данных основывается на пассивном восприятии и не учитывает субъективной избирательности ментального акта. Наконец, К. Поппер в своей «Теории Прожектора» переносит эпистемологическое учение об активности субъекта на уровень методологии науки, полагая, что научное дедуктивное 
гипотетическое положение предпосылается исследованию. Однако в пространстве аналитической философии никто до Серля не связывал аспектуальность с интенциональностью сознания; и в этом новизна его концепции, которая, в отличие от прочих, может быть названа «феноменологически ориентированной».

Интенциональность понимается здесь как форма внутреннего onıma. Понимание сознания в духе экстернализма возможно; но в нем нет ничего «рационального». И животное чувствует раздражимость, но оно не выстраивает внутреннего «феноменального ряда», сопровождающего и организующего поток переживаний. Тут теория интенциональности смыкается с аргументом «Китайской комнаты» (предложенном Серлем), в котором доказывается бесплодность претензий внешней имитации на обладание статусом понимания чужого языка. В сущности, интенциональность относится лишь к моменту намерения, осознания, иелеполагания ментального акта; то есть она выступает формой не только сознания, но и самосознания, не только рефлексии, но и диспозиции. Отсюда и критерий успешности интенциональности должен носить внутренний, интерналистский характер. «Интенциональное содержание определяет условия достаточности» (Searle, 1983, 12), - отмечает Серль. Сразу бросается в глаза подчеркнутая, прагматистски выверенная «субъективность» категории «достаточность». Она трактуется как достижение гармонического состояния удовлетворенности, которое достигается между интенцией и результатом ментального акта. К примеру, мы хотим полюбоваться видом Средиземного моря, предвкушая, как мы туда полетим, как мы увидим теплые бирюзовые воды, что мы почувствуем, если решим окунуться в это море или поплыть по нему на белоснежной яхте. «Достаточность», как ее понимает Серль, достигается лишь в том случае, если реальность наших восприятий оправдает ожидания. «Ключ к пониманию интенциональности это условия достаточности. Интенциональное состояние, такое как убеждение, надежда, страх или намерение, с направленной целью, есть репрезентация собственных условий достаточности» (Searle, 2002, 145), - пишет Серль. Но достижима ли эта достаточность? Не уподобляется ли человек вечно неудовлетворенному страннику в мире собственных интенций? На этот вопрос Серль, к сожалению, ответа не дает, просто предполагая, что достижение достаточности вполне возможно теоретически. Он считает, что достаточность - довольно 
«гибкая» категория; и интенциональные цели «подстраиваются» под реальные возможности и положения дел.

Если в «Интенциональности» Серль трактует интенциональность на уровне индивидуального субъекта, то в 1990-е гг. он приходит к теории коллективной интенциональности. «Коллективная интенциональность позволяет группам людей создавать общие институциональные факты, связанные с деньгами, собственностью, бракосочетаниями, управлением и, самое главное, языками» (Serl', 2004, 75), - пишет Серль. Такая интенциональность не имеет субстанциального значения, а возникает в случае совпадения интенциональных актов у нескольких субъектов. Поэтому коллективную интенциональность можно обнаружить, прежде всего, в формах массового поведения; она особенно ощутима, к примеру, на стадионе, когда многочисленная толпа смотрит футбольный матч, и каждый наряду с окружающими ожидает голов и победы любимой команды. В случае коллективной интенциональности наблюдается конгениальная интерсубъективность, родственность, однотипность частных интенциональных актов. «Коллективная интенциональность проявляется в совместных формах поведения, которые мы категориально описываем не как случаи, когда я делаю что-либо или вы делаете что-либо, а когда мы делаем что-либо вместе» (Searle, 2002, 139), - отмечает Серль. Д. Деннет (Dennett, 1994) считает, что местоимение «Вы» нельзя приписать существу, не обладающему сознанием. Нельзя, к примеру, сказать: «Мы пообедали я и моя вилка». По Серлю, «я» и «вы» объединяются в «мы»; следовательно, можно говорить об «общец̆», «нашец̆», «объединяющей» интенциональности. В Сопоставлении III мы предпримем детальный сравнительный анализ гуссерлевской теории интенциональности и серлевской теории коллективной интенциональности. Здесь же отметим, что теорию коллективной интенциональности можно подвергнуть критике за неопределенность и механистичность онтологического понимания коллективного субъекта интенциональности. Однако, безусловно, эта теория является новым словом, настоящим прорывом. Роль Серля в изучении интенциональности сопоставима с ролью К. Юнга в истории психоанализа, повернувшего исследования бессознательного от индивидуума к социуму. Таким образом, коллективная интенциональность - это новый взгляд на классическую феноменологическую проблему интерсубъективности и жизненного мира. 


\section{III. ДРУГИЕ КОНЦЕПЦИИ ИНТЕНЦИОНАЛЬНОСТИ В АМЕРИКАНСКОЙ ФИЛОСОФИИ}

В этом разделе мы рассмотрим некоторые другие концепции интенциональности в американской философии, хотя их полный обзор невозможен в пределах статьи. Во введении мы уже отмечали, что многие американские авторы пишут о феноменологии или обсуждают феноменологические проблемы, но нас интересуют, прежде всего, те из них кто занимается положительным рассмотрением феноменологических проблем. Поэтому мы выбрали двух авторов: Э. Томпсона и Д. В. Смита.

Книга Э. Томпсона «Сознание в жизни. Биология, феноменология и наука о разуме» (Thompson, 2007) олицетворяет собой интерес к междисциплинарным исследованиям, характерным для философии сознания 2000-2010-х гг. Томпсон способен свободно и компетентно рассуждать в рамках предметов сразу трех наук: философии, нейрофизиологии и биологии. Понятие интенциональности центрирует метафизические и естественнонаучные теории сознания; оно играет в системе Томпсона синтетическую роль. Сама по себе интенциональность понимается крайне абстрактно. «Интенциональность, понимаемая в самом широком феноменологическом смысле, открыта по направлению к миру» (Thompson, 2007, 383), - пишет Томпсон. Интенциональность, тем самым, - это основа активности, избирательности, заинтересованности сознания; это форма освоения мира, придания ему значимости во внутреннем мире субъекта. В творчестве Томпсона налицо тенденция отхода от натуралистического понимания интенциональности, свойственного Серлю. Он считает, что крайне затруднительно описать интенциональность как биологический феномен, даже при допущении того, что интенциональность нельзя объяснить без привлечения физических и телесных понятий. Томпсон пишет: «В феноменологической перспективе объекты представлены способом, каким они, как сложно структурированные проявления видимости, подчиняются существенным формальным законам, которые управляют с необходимостью опытом в той же степени, что и миром значений» (Thompson, 2007, 239). Таким образом, налицо тенденция к метафизическому, формальному пониманию природы интенциональности, поворот к «чистому» пониманию интенциональности.

Д. В. Смит определяет интенциональность не менее абстрактно, чем Томпсон. «Интенциональность суть структура, посредством которой мы 
узнаем о мире» (Smith, 2004, 1), - пишет он. Для Томпсона характерно понимание интенциональности не только как способности, но и как структурь сознания, стремление выделить ее в особый уровень человеческого сознания. При этом Смит окончательно отходит от натуралистической трактовки интенциональности, которая свойственна Серлю. «Однако структура интенциональности [...] вовсе не вытекает легко из эмпирических “натуралистических" исследований мозга, телесного поведения или физической системы самой по себе» (Smith, 2004, 14), - отмечает американский философ. Тем самым, налицо новый «антинатуралистический поворот» в современной американской трактовке интенииональности, который, конечно, не дает никакой возможности допускать наличие «трансцендентального толкования», но который, вместе с тем, дает недвусмысленную возможность предположить, что Гуссерль гораздо более значим для Томпсона и Смита, нежели для Серля.

Другим новым аспектом, который до Смита не разрабатывался в США, является контекстуальное понимание интенциональности. Подобно Куайну, который считал, что слово нельзя понять вне языкового контекста, Смит рассуждает не об атомарном интенциональном акте, а о контексте интенциональных состояний сознания. «Очень кратко, содержание теории интенциональности, которую я предпочитаю, включает в себя то, что интенциональность состоит из сложной структуры контекста, субъекта, действия, содержания и объекта. То есть внутри определенного контекста личность, или субъект, совершает или испытывает акт сознания (мышление, видение, желание и т. д.) с определенным содержанием (мысль, образ и т. д.), который представляет или “направляется" на определенный объект (личность, положение дел, событие и т. д.)» (Smith, 2004, 2), - пишет Смит. Субъективность трактуется, прежде всего, как индивидуальный интенциональный контекст. Каждый интенциональный акт имеет как собственное, так и контекстуальное значение. Внесение холистического критерия интенционального контекста порождает, вместе с тем, целый ряд трудностей. Во-первых, неясно, обладает ли интенциональный контекст самостоятельным бытием; непонятно «надстроечное» положение такого контекста. Во-вторых, погруженность интенционального акта в контекст «стирает» индивидуальность частного интенционального акта, который, как таковой, может быть отделен от других по самым разным критериям внутреннего и внешнего характера. В этой связи, теория интенционального контекста интересна как гипотеза, но ее обоснование требует выхода на уровень иного концептуального языка, к чему Смит не готов. Однако это 
позволяет сделать вывод, что современное понимание интенциональности в США постепенно теряет зависимость от исследования индивидуального сознания. Это теория коллективной интенциональности и теория контекста интенциональных актов.

Теория Смита, в отличие от теории Серля, уже не ограничивается интересом к Гуссерлю, а стремится включить в себя некоторые идеи немецкого классика. Смит так пишет о собственной теории:

Мой подход к феноменологии - это синтетический подход, который объединяет воедино классическую феноменологию (особенно основанную на трудах Гуссерля) с логико-семантической теорией (традиция Фреге, Тарского, Карнапа, Хинтикки и Каплана) и, я хочу добавить, с современной нейронаукой о сознании (в духе Серля и прочих, кто серьезно принимает во внимание сознание). (Smith, 2004, 300)

Авторы середины ХХ в., которые писали о феноменологии (например, М. Даммит и Дж. Пассмор) находились под влиянием расселианского взгляда о принципиальной несовместимости оснований феноменологии и аналитической философии (что не исключало положительного отношения к феноменологии). В принципе, Серль, находясь в «промежутке» между феноменологией и аналитической философией, еще не покинул пространство расселианского взгляда. Поэтому можно предположить, что Смит обозначает новую тенденцию американской философии 2000-х гг.: появление национальной школы феноменологических исследований и авторов, которые будут включать в свои концепции положения философии Гуссерля.

Обращение к Гуссерлю, однако, не следует переоценивать. Американские теории интенциональности по-прежнему остаются эмпирическими по своей сути, что служит препятствием для принятия гуссерлевского учения о «заключении в скобки» содержания опыта. По этому поводу Смит пишет следующее замечание: «Гуссерль противостоит натурализму как такой онтологии, которая сводит сущность сознания и интенциональности к физико-биологическим свойствам» (Smith, 2004, 200). Само собой разумеется, что собственная теория Смита не свободна от связей с понятиями нейрофизиологии и других частных наук. Однако Смит отмечает несогласие с Гуссерлем в сдержанной манере, тогда как Серль прямо критикует Гуссерля за непонимание природы опыта:

Феноменологи типа Гуссерля видели взаимосвязь опыта и значимости взгляда от первого лица; но они не могли усмотреть уместность причинности, потому 
что их понимание абстрактного характера интенционального содержания привело их к допущению, что причинность суть всегда естественное, не-интенциональное состояние. (Searle, 1983, 65)

Тем самым, интенциональность, как ее трактуют американские философы, постепенно теряя свою зависимость от натуралистических теорий сознания, остается, по своей сути учением об интенциональности восприятия, а не учением о чистой интенциональности.

\section{IV. СОПОСТАВЛЕНИЕ I: \\ ГУССЕРЛЬ И АМЕРИКАНСКИЕ ТЕОРЕТИКИ ИНТЕНЦИОНАЛЬНОСТИ О ПРИРОДЕ ОПЫТА.}

В этом и двух последующих разделах мы будем заниматься уже не рассмотрением идей Серля, Томпсона, Смита и других американских теоретиков интенциональности, а сравнительным анализом их воззрений с идеями Гуссерля с целью выявления сходств и различий. В этой связи, в этом сопоставлении (равно как и в двух последующих) взглядам Гуссерля будет уделено более пристальное внимание. Также особо оговорим, что для ясности картины большую часть сопоставлений занимает ведущий план: сравнительный анализ идей Гуссерля и Серля.

Гуссерль строит свою теорию опыта на основе критики эмпирической точки зрения. Он считает, что для эмпирика наука - это анализ содержания чувственности. Современную форму эмпиризма Гуссерль усматривает в позитивистской точке зрения (к которой он причисляет и неореалистические учения). Типичной современной Гуссерлю теорией, которую он критикует, можно считать эпистемологию Дж. Мура (правда, следует оговорить, что Гуссерль крайне редко критикует теории конкретных философов, предпочитая критиковать «эмпириков» и «позитивистов» вообще). Согласно Муру, существуют физические объекты и чувственные данные (или образы восприятия фактов), которые порождаются сознанием. Хотя субъективное восприятие и не лишено активности, в эпистемологии Мура, в целом, господствует принцип соответствия (корреспонденции), согласно которому чувственные данные, во-первых, вторичны по отношению к физическим объектам и, во-вторых, они обладают эпистемологической значимостью лишь в случае полного или частичного совпадения с объектами. Именно против такого «эмпиризма», превращающего опыт в анализ пассивно отражающей чувственности, и выступает 
Гуссерль, выдвигая эйдетическую концепцию опыта. «В себе сущий предмет никогда не бывает таким, чтобы сознание и “я" сознания не имело касательства к нему», - пишет Гуссерль (Gusserl', 1999, 104). Тем самым, являющиеся в переживании предметы суть в то же время и предметы осознающиеся, попадающие в эйдетическое предметное поле и, тем самым, находящиеся внутри конструируемой сознанием сущностной целостности, которая и может быть названа «осмысленным миром». В «Идеях феноменологии» Гуссерль проводит политику полного преодоления психологизма. Он пишет: «Мы окончательно покидаем почву психологии, даже [психологии] дескриптивной» (Gusserl', 2006, 53).

Здесь можно обратиться к американским теориям опыта. Эпистемологические доктрины Серля и других рассмотренных в этой статье авторов - это теории в рамках эмпирически ориентированной эпистемологии. Следовательно, они базируются на анализе всех форм актуального опыта, в том числе и чувственного опыта, или ощущения. Поэтому ни о каком «преодолении психологизма» у американцев речи идти не может. Другое дело, что Серль мыслит уже в парадигме аналитической эпистемологии, которая существенно иная, нежели эпистемология Мура, Уайтхеда, Рассела и других ранних теоретиков аналитической философии. Концепция Серля, наряду с неореалистическими основами, вбирает в себя прагматистские и феноменологические положения, а это позволяет перекинуть мост от аналитической эпистемологии к феноменологии, усмотреть точки схождения. Прежде всего, следует отметить, что Серль стоит на позициях принципиальной активности познающего субъекта; он выступает убежденным противником сенсуалистической теории отражения во всех ее формах. Здесь стоит подчеркнуть, что американские теории интенциональности суть не только аналитические, но и прагматистские теории. Исследователи творчества Гуссерля справедливо отмечают определенную схожесть между его концепцией опыта и воззрениями ранних прагматистов, и особенно У. Джеймса (Spiegel'berg, 2002, 134). По Джеймсу, любой значимый для науки акт опыта неотделим от волевого акта, направленного на достижение практического успеха и обеспечения дальнейших перспектив исследования. По Серлю, который находится в пространстве поздней, неопрагматистской философии, имеется существенное отличие: существует теоретическая возможность выделить такие акты опыта, которые сопровождаются интенциональными актами, среди которых ведущее место занимает придание содержанию опыта определенного аспекта. Серль, Томпсон, Смит, Дретске и другие теоретики феноменологии, на наш взгляд, 
полностью отказались от того, что У. Селларс называет «Мифом Данного», то есть от эмпирической веры в то, что акты опыта могут отражать физические объекты в их наличной данности. Перед тем, как снова вернуться к Гуссерлю, мы хотим высказать довольно смелую гипотезу: теория опыта Серля значительно ближе к теории феноменологической редукиии Гуссерля, нежели $\kappa$ теории чувственных данных Мура. Серль и другие американские теоретики интенциональности, хотя и являются чуждыми стремлению к чистой феноменологии, тем не менее утверждают необходимость анализировать только такое содержание опыта, которое неотделимо от усматривающей, преобразующей, трансформирующей деятельности сознания. Можно предположить родство между Гуссерлем и Серлем, поскольку есть возможность обнаружить общий им обоим мир опыта, который суть опыт субъекта, человеческий опыт, опыт-по-обнаружению-сущности.

В «Логических исследованиях» Гуссерль пишет: «Всякое познание “начинает с опыта", но из этого не следует, что уже вследствие этого оно “проистекает” из опыта» (Gusserl', 2011, 79). Учение Гуссерля, на наш взгляд, согласуется с учением Серля в том, что оба мыслителя видят в чувственности лишь основу, которая существенна с натуралистической точки зрения, но не играет значительной роли с точки зрения гносеологической. В своем учении об аспектуальности Серль подчеркивает, что природа аспектуальности присуща исключительно человеческому сознанию. Не исключая возможности установления натуралистического происхождения аспектуальности, Серль, тем не менее, подчеркивает ее уникальное своеобразие, констатируя пропасть между человеческим и животным сознанием. Способность действия по обдуманному плану, способность выделения цели и следования ей, способность формирования сущности явления или объекта - эти выделяемые Серлем черты «исключительно человеческого» сознания были, на наш взгляд, уже отмечены и проработаны в трудах Гуссерля. Другое дело, что, находясь в рамках «классической» философской парадигмы, Гуссерль даже не допускал возможности иной рациональности, нежели рациональности человеческого сознания. Если смотреть на теорию Гуссерля в сравнении с теорией Серля, то теория немецкого мыслителя - это обретение подлинно идеалистической точки зрения на сознание, редуцирование всего содержания Я к чистой идеальности, совершенно свободной от противоречий между материализмом и феноменализмом, которые сотрясают коллизиями здание системы Серля. По Гуссерлю, очевидность это обретение содержания опыта перед духовным взором; совершенная же 
очевидность носит идеальный характер. Путь Серля к очевидности гораздо более тернист. Серль тратит огромные усилия, чтобы доказать, что аналитическая эпистемология пребывает в рамках ложного физикализма, тогда как на самом деле любой опыт субъективно окрашен вследствие введения в него пред-посланного аспекта. Серль близок к феноменологии не только потому, что он следует Гуссерлю и другим феноменологам, а потому, что он своим путем приходит кфеноменологической по своей сущности точке зрения о неотделимости акта опьта и редукиии содержания этого акта к сбере сознания. Человеческий опыт, по Серлю, разнообразен, но в своих высших формах он интенционален и подвергается столь радикальному преобразованию, что совершенно теряет свою «физическую», «естественную» сущность, обретая взамен иную символическую, эйдетическую сущность, где правит уже не чувственность, а выведенная Серлем «аспектуальность». Для сравнения, Гуссерль пишет о сущностном преобразовании опыта так:

Посредством феноменологического غ̇лохиं я редуцирую свое естественное человеческое Я и свою душевную жизнь - сферу своего психологического опыта своей собственной данности - к своему трансцендентально-феноменологическому Я, к сфере трансцендентально-феноменологического опыта своей собственной данности. (Gusserl', 2010, 40)

При этом Гуссерль понимает Я с трансцендентальной, субъективно-идеалистической точки зрения. И хотя Серль такой позиции не придерживается, не будет натяжкой предположить, что он, по большому счету, схожим образом понимает природу Я, хотя озабочен не трансцендентальными аргументами, а доказательством качественного отличия человеческого сознания от животного сознания. Серль разделяет точку зрения Д. Дэвидсона об «аномальности» человеческого сознания в природе; причем интенциональность - одна из главных черт этой аномальности, уникальности именно человеческого Я. По большому счету, Серль убежден, что категорию «Я» можно отнести только к человеку; поскольку «быть Я» - это значит иметь внутренний феноменальный ряд, который не только наличествует, но и осознается. Конечно, Серль по отношению к Гуссерлю более лоялен к «эмпирической» позиции. Отвергая ее лишь частично, он не стремится к учению о чистом сознании; и в этом отношении Серль открыт другим феноменологическим проектам: Брентано, Финка, Мерло-Понти и даже Хайдеггера. Однако из всех феноменологов Гуссерль, на наш взгляд, остается наиболее близким Серлю, поскольку для Серля, как и для Гуссерля имеет особое значение проблема редукции содер- 
жания чувственности к содержанию сущностно иной, высшей сознательной деятельности Я.

Как отмечает Ф.-В. фон Херрманн: «Критика, обозначенная Гуссерлем как прояснение проблем, направлена против натурализации сознания и идей» (Herrmann, 2000, 15). В приведенной цитате следует особо выделить слово «натурализация»; Гуссерль считает чистое Я не смешанным с естественным, природным Я. Серль, начиная с монографии «Интенциональность» (Searle, 1983), также выступает против натуралистического рассмотрения сознания. Однако его путь к такому убеждению гораздо более драматичен, нежели у Гуссерля, поскольку поворот к интенциональной теории сознания для Серля зачеркивает прежний этап его философской эволюции. Серль отбрасывает свои прежние идеи, такие как, к примеру, материализм и теорию машинного интеллекта. Нетрудно проследить, что движение Серля к идее интенциональности - это процесс постепенного «очищения» сознания от натуралистического понимания. В этом отношении Серль действительно выглядит на фоне американских аналитиков «феноменологически ориентированным» автором, поскольку он отбрасывает саму возможность любого натурализма относительно разума и эмпиризма относительно опыта. Тем самым, движение Серля к интенциональности - это, если взглянуть на его систему, - начало сущцнотного сближения аналитической философии и феноменологии, стремление уйти от классической для всей аналитической философии эпистемологии чувственных данных, а также стремление преодолеть не менее классическое для аналитической философии юмистское понимание сознания как естественного феномена. В конце концов, интенциональность у Серля - это базисное условие понимания, форма направленности сознания, причем как в сфере опыта, так и в сфере рациональности. Серль согласился бы с мнением, которое высказывает о Гуссерле Д. Разеев: «Ошибка психологизма как раз и заключалась в том, что явление предмета признавалось за сам предмет, который является» (Razeev, 2004, 69). В отказе от отождествления предмета и явления предмета в опыте, свойственного теории чувственных данных, Серль не одинок в американской философии; схожие идеи выдвигали У. В. О. Куайн, У. Селларс, Д. Дэвидсон, С. Крипке, Р. Рорти, Д. Деннет и др.

Отмечая близость идей Серля и Гуссерля, мы не должны забывать, что Гуссерль тоже прошел сложную эволюцию, порой меняя свои взгляды. Феноменология Гуссерля - вовсе не некий незыблемый «эталон», который прикладывается ко всем феноменологическим концепциям. Сама система 
Гуссерля не свободна от внутренних противоречий. К примеру, В. Куренной отмечает, что теория Гуссерля формировалась за счет многочисленных заимствований у Брентано, Мейнонга, Фреге, Липпса и др. В. Куренной критикует Гуссерля за недооценку значимости эмпирических критериев опыта, когда пишет: «Гуссерль всю жизнь остался представителем философии “письменного стола", априористской традиции, которая при всем акценте Гуссерля на “опыт" была чужда многообразию человеческого опыта» (Kurennoy, 2012, 80). Аналогично судит и Н. В. Мотрошилова, которая отмечает неспособность Гуссерля строго разграничить чистые и эмпирические переживания (Motroshilova, 1968, 47). В свете такой точки зрения можно придти к убеждению, что, наоборот, не Гуссерль, а Серль правильно понимает опыт; поскольку он не стремится «взять в скобки» естественный опыт, а лишь стремится придать ему феноменологическое измерение. Поэтому, если в некоторых аспектах нельзя отождествить идеи Гуссерля и Серля, то это вовсе не означает того, что идеи Серля не окажутся ближе другим феноменологическим концепциям, к примеру, феноменологии восприятия Брентано, Финка и Мерло-Понти. Более того, как же Серлю относиться к Гуссерлю, если даже его ученики Финк, Шелер, Хайдеггер - не раз отмечали определенную «старомодность» его воззрений на опыт? Так, например, А. Паткуль подмечает то, что Финк «опознает существо феноменологии Гуссерля как позитивизм» (Patkul', 2016, 91), причем в весьма «заурядной» (по словам Финка) форме. Исследователи Гуссерля не раз отмечали, что Гуссерль был постоянно озабочен тем, что «взятый в скобки» жизненный мир все равно не удается «выключить». Так П. Прехтль отмечает: «Предметное представление не означает для Гуссерля представления вещественного предмета, известного нам из восприятия» (Prekhtl', 1999, 19). Не означает ли это того, что вместе с естественной установкой будет «выключен» и «естественный» мир? На этот вопрос можно дать разные ответы; мы же приведем ответ Серля, согласно которому интенциональность, по большому счету, ничего не меняет в бытии мира. Интенциональность определяет исключительно человеческую форму представлений о реальности. Мы просто не можем смотреть на мир иначе, как с интенциональной точки зрения. Нет никаких «до-интенциональных данных». Как высказался Х. Патнэм (и Серль совершено с этим согласен): «Сами исходные данные, на которые опирается наше знание, являются концептуально инфицированными» (Patnem, 2002, 77). 
Тем самым, из сопоставления I можно заключить, что между теориями опыта Гуссерля и Серля (равно как и других теоретиков интенциональности в США) присутствует существенное сходство, которое наиболее ощутимо в критике сенсуализма и трактовке роли субъективности в опыте. Гуссерль и американские теоретики проблемы интенциональности объединены одной теоретической проблемой: как описать «выход» сознания к вещам? К философии Серля можно приложить суждение, которое А. Савин высказал о Гуссерле: «Феноменологическая философия есть генеалогия доверительного знакомства с миром, выполняющаяся в свете понятия горизонтности и осуществляющая благодаря этому постоянную проблематизацию своей позиции» (Savin, 2015, 35). «Человеческая форма реализма», ведущим представителем которой выступает Серль, также постулирует неотъемлемость установленной субъектом «перспективы» (prospect) в любом значимом акте опыта.

\section{V. СОПОСТАВЛЕНИЕ II: \\ ГУССЕРЛЬ И АМЕРИКАНСКИЕ ФИЛОСОФЫ О ПРИРОДЕ ИНТЕНЦИОНАЛЬНОСТИ}

В этом сопоставлении мы подошли к центральному разделу всей статьи, а именно: к подробному сравнительному анализу концепций интенциональности Гуссерля, Серля и других американских философов.

Гуссерль, как правило, употребляет понятие «интенциональность» в общем смысле - быть сознанием о чем-либо. Интенциональность - это помещение предмета в сферу cogito. Как видно, понимание интенциональности как акта сознания у Гуссерля и Серля довольно схожи; однако нельзя сделать вывод, что Серль следует Гуссерлю в понимании интенциональности как способности. Серль находится в теоретическом пространстве аналитической эпистемологии, в рамках которой сильны эмпирические позиции и ярко выраженный эмпирический редукционизм, согласно которому ментальные акты рассматриваются не только сами по себе, но и через проявления в опыте. Интенциональность проявляется в том, что мы выделяем в природе объект, делая его предметом опыта, который, как таковой, уже неотделим от опыта, слит с ним. К примеру, Серль пишет о визуальном опыте: «Визуальный опыт в значительной степени управляется объектами и состояниями вещей в мире, равно как и любая другая парадигма интенциональных состояний 
[...] такая как убеждение, страх или желание» (Searle, 1983, 39). Серль особо подчеркивает реалистический характер своей теории интенциональности, что контрастирует с гуссерлевским учением о cogito. Сама по себе интенциональность не вносит в мир никакого особого «интенционального объекта». Она выступает исключительно формой руководства нашими ментальными актами, по большому счету никак не меняя их природу, а лишь «очеловечивая» как их, так и их предмет. Тем самым, по-видимому, интенциональность это базовая форма первичной заинтересованности, удовлетворения интереса к объекту, превращения объекта в нечто «освоенное». Серль понимает интенциональность в прагматистском ключе, обращая внимание, прежде всего, на функционирование интенциональности и обоснование ее места, роли в познании.

Однако, обращаясь к другим феноменологически ориентированным Ђаналитикам, следует отметить, что существуют трактовки интенциональности, более близкие трактовке Гуссерля. К примеру, как мы уже писали в разделе III, Томпсон судит об интенциональности как о чистой «открытости» по отношению к вещам. Смит также приходит в своем творчестве к чистому пониманию интенциональности как полностью не-натуралистического феномена, вводя концепт интенционального контекста. Тем самым, хотя позиция Серля об интенциональности остается самой известной и популярной в США, некоторые представители младшего поколения уже не придерживаются теории натуралистической интенциональности, переходя на гуссерлианские позиции.

Сопоставление взглядов Гуссерля и Серля затруднено и тем, что зачастую два философа понимают одну и ту же категорию в разных значениях. Так, Гуссерль отмечает, что следует учению Брентано в том, что «интенциональность следует считать свойством психических феноменов» (Gusserl', 2010, 59). И там же он пишет о необходимости «метода дескриптивного учения о сознания». Нас здесь интересуют термины «психическое» и «дескрипция». По Гуссерлю, эти термины относятся к сфере чистой рациональности, или cogito. По Серлю, психические феномены суть формы ментальных актов, а дескрипции суть субъективно окрашенные описания предметов этих актов. Однако, при разных категориальных языках, мы осмелимся предположить, что, в своей сущности, и Гуссерль, и Серль одинаково понимают природу интенциональности как преобразующей предмет восприятия сознательной деятельности вообще. Гуссерль и Серль стремятся обосновать естественность интенци- 
ональности как психического феномена, отнесение ее к внутренней сфере сознания. «Данности» восприятия в обеих концепциях - это предметы, а не ощущения сами по себе. Поэтому, если вывести позицию Брентано в качестве «посредника», то взгляды Гуссерля и Серля могут быть успешно сближены на фундаменте феноменологической психологии. При этом, однако, следует учесть важную оговорку Г. Шпигельберга, в которой определяется отличие позиции Гуссерля от позиции Брентано: «Выражения “интенциональный” и “интенциональность” относятся к реляционному свойству быть интенцией или быть предметом, на который направлена интенция» (Spiegel’berg, 2002, 117).

Теперь перейдем к гуссерлевскому учению о горизонтном характере интенциональности. Он пишет: «Любое переживание обладает особым горизонтом, меняющимся в процессе изменений связи сознания и изменения протекающих фаз этого переживания» (Gusserl', 2010, 62). Горизонтная структура интенциональности требует нового метода анализа восприятий, в рамках которого не отделяются друг от друга содержание восприятия и преобразованная в сознании его форма. Не менее важно и то, что любой феномен воспринимается уже в а priori сформированном «горизонте». Это учение Гуссерля, как можно судить, прямо и существенно повлияло не только на эпистемологию Серля, но и на американский неопрагматизм вообще. В самом деле Серль, наряду с Куайном, Патнэмом, Дэвидсоном, Рорти и другими американскими мыслителями, выступает убежденным сторонником эпистемологического uнтерпретационизма, стремясь доказать следующий принцип: нет никакого ментального акта, который не был бы свободен от установки интерпретаиии, которая и осуществляется благодаря интенциональности. По Серлю, любой акт восприятия помещен в определенную «перспективу» (prospect), которая задается выбором «аспекта». На наш взгляд, между учением Гуссерля о горизонте и учением Серля о перспективе нет существенных различий на гносеологическом уровне; оба мыслителя понимают функционирование сознания в рамках горизонта довольно схоже. Различие нарастает на онтологическом уровне, поскольку Серль, конечно, не придает регионам онтологического статуса. Перспектива для него - это, скорее, прагматистски понимаемая «установка», которая обладает исторической изменчивостью, в том числе и на уровне механизмов функционирования сознания. Однако еще раз повторим, что онтологические различия между Гуссерлем и Серлем не так существенны для понимания природы интенциональности, как гносеологические подобия. 
Гуссерль подчеркивает «имманентный» и «имплицитный» характер интенциональности, которая выполняет функцию «конструирования переживаний в качестве имманентных временных предметов» (Gusserl', 2010, 105). Учение Гуссерля здесь согласуется с развернутой Серлем критикой принципа «экстернализма». Согласно Серлю, любое понимание невозможно без осознания внутреннего феноменального ряда. Это следует из серлевского аргумента «Китайской комнаты», согласно которому человек, видящий китайские иероглифы и имеющий словарь, где указано, как следует произносить и переводить эти иероглифы, лишь имитирует, но никак не понимает сознание носителя китайского языка. Выводом из аргумента является учение о «внутреннем» (internal) характере любого восприятия, которое при этом неотделимо от момента интерпретации (в самых разных смыслах: от частного мнения до экспертной оценки). Заметим a propos, что в американской эпистемологии присутствуют еще более яркие теории внутреннего характера опыта, к примеру: теория «интернализма» Х. Патнэма и теория критики «зеркального отражения» Р. Рорти, положения которых Серль включает в свою концепцию интенциональности. Таким образом, можно предположить, что Гуссерль и Серль одинаково понимают феномен интенционального акта как исключительно внутреннего акта сознания. При этом также нельзя исключить и прямого влияния Гуссерля на Серля, поскольку уникальность эпистемологии Серля на американской сцене состоит в том, что он, в отличие от таких философов, как Патнэм, Рорти или Деннет, считает невозможным обойтись без учения об интенциональности сознания и разрабатывает это учение. Интенциональность для Серля сущңностно необходима для понимания деятельности сознания.

В «Идеях І» Гуссерль пишет: «Модусом “актуальность” обладает не только представление чего-либо, но обнимающее его оценивание» (Gusserl', $1999,82)$. Оценивание суть высматривание сущности, превращение наличной совокупности «данного» в феномен. Интенциональность Серля также не свободна от оценивающего аспекта. Это не просто видение, а видение-как, то есть представление об объекте или явлении в свете того или иного аспекта, который, при этом не является внешним и добавочным по отношению к «контенту» восприятия, а неразрывно и органично слит с ним в единое целое. Характерно, что и Гуссерль употребляет термин «перспектива», а именно: в своих «Амстердамских докладах», где он пишет: «То, что из воспринятой вещи действительно дано в созерцании, дано так, что каждый момент созер- 
цаемого имеет свой способ данности, например, визуально дан в соответствующей перспективе. При этом перспектива тотчас указывает на возможные новые перспективы» (Gusserl', 2005, 313). На наш взгляд, понимание «перспективного» характера восприятия практически идентично для Гуссерля и Серля. Правда, следует оговорить особо, что в «Амстердамских докладах» Гуссерль ведет речь о «психологическом» уровне восприятия; в учении о чистой интенциональности принцип перспективности не фигурирует. Н. В. Мотрошилова так пишет об оценивающем уровне сознания у Гуссерля: «Образ разума, каким его набрасывает феноменология, ближе всего сопрягается с актами, процедурами, формами сознания, обеспечивающими изначальную и адекватную (очевидную) интуитивно-созерцательную данность предметных смыслов сознания (ядра ноэм)» (Motroshilova, 2003, 517). Здесь мы хотели бы обратить внимание на два качества интенциональности, которые характерны для Гуссерля и Серля, а именно: неотьемлемость от акта восприятия и интуитивно-созериательную перспективность. И Гуссерль, и Серль неоднократно определяют интенциональность как данность, структуру человеческого сознания, определяющую способность восприятия в целом. При этом следует особо подчеркнуть, что интенциональность у обоих мыслителей - это не просто структура организации восприятия в сознании, но и структура отсылания сознания к «прошлым» или «будущим» восприятиям. Относительно учения Гуссерля о воспоминании пишет О. Финк: «В интенциональный смысл воспоминания включена - замечаем мы это или нет - смысловая отсылка обратно к восприятию» (Fink, 2016, 26). То есть интенциональные акты сознания не только организуют, но и реконструируют и предвосхищают картину сознания. Однако не лишено истинности и мнение Г. Чернавина, который считает, что «для Гуссерля трансформация субъекта в процессе феноменологической работы - это побочный продукт» (Chernavin, 2016, 70). Финк не зря видит у Гуссерля не только динамику, но и статику его системы, стремление обрести в cogito завершенное в себе и законченное основание. Серль, вне всякого сомнения, глубоко чужд универсалистским стремлениям Гуссерля выстроить вокруг интенциональности метафизику, что, как мы убедились, не мешает обнаруживать целый ряд существенных сходств. Подводя итог этого сопоставления, можно отметить, что между учениями об интенциональности Гуссерля и Серля в эпистемологическом (гносеологическом) отношении гораздо больше сходств, нежели отличий. Оба мыслителя примерно одинаково описывают функционирование интенциональности сознания. Различия начи- 
нают нарастать тогда, когда речь идет об определении онтологического статуса объекта восприятия; здесь Серль не присоединяется к учению Гуссерля о чистых феноменах. Однако это вовсе не означает того, что учение о феноменах не имеет значения для Серля; просто он трактует феномены как символические структуры сознания, которые отнюдь не чисты, но изменчивы вместе с эволюцией самого этого сознания. Однако это различие, на наш взгляд, уже лежит далеко за пределами теории интенциональности.

VI. СОПОСТАВЛЕНИЕ III:

ГУССЕРЛЬ И АМЕРИКАНСКИЕ ТЕОРЕТИКИ НТЕНЦИОНАЛЬНОСТИ О СУБЪЕКТИВНОСТИ И ИНТЕРСУБЪЕКТИВНОСТИ

Наше исследование будет неполным, если мы не проведем сопоставление взглядов Гуссерля и американских теоретиков о том, как следует понимать индивидуальный и социальный субъекты. Проблематика cogito, определения природы чистого Я для Гуссерля не менее важна, чем решение проблемы соотношения сущности и тождественности сознания (entity-identity problem) для Серля. Также проблематика интерсубъективности для Гуссерля не менее важна, чем проблематика «социального действия» для Серля. Попытаемся провести сравнительный анализ с целью выявления сходств и различий.

Гуссерль строит свое учение о Я с позиций картезианского рационализма. Я понимается как чистое Ego и предшествует бытию мира. Если задаться вопросом: «Что такое сознание по Гуссерлю?», то ответом будет следующее: «Сознание в себе самом наделено своим собственным бытием, какое в своей абсолютной сущности не затрагивается феноменологическим выключением» (Gusserl', 1999, 75). В своем индивидуальном бытии человек пребывает в двух планах: как психофизический субъект в реальном мире и как трансцендентальный субъект в мире идей. «Благодаря феноменологическому эпохэ естественное человеческое Я, и притом мое, редуцирует себя к трансцендентальному, - это и имеется в виду, когда речь идет о феноменологической редукции», - пишет Гуссерль (Gusserl', 2005, 350). Н. В. Мотрошилова так уточняет суть гуссерлевского учения о Я: «Для анализа сознания феноменолог не нуждается ни в чем, кроме своего сознания как поля сущностного созерцания» (Motroshilova, 2003, 325). Феноменологический анализ Я, тем самым, - это анализ сознания индивидуального субъекта, который понимается как чистая в себе сущая рациональность. 
Теперь обратимся к Серлю. Находясь в пространстве аналитической традиции, Серль, вне всякого сомнения, довольно скептически относится к идее чистого Я. Хотя Серль и выступает последовательным критиком физикализма относительно сознания, он не склонен рассматривать сознание как чистую сущность. В отличие от Гуссерля, Серль стоит на позициях метабизического скептицизма относительно возможности определения «сущности» сознания. Вместо построения метафизических теорий Я, Серль предпочитает сосредоточиться на анализе деятельности Я, или так называемых «ментальных актов».

Однако можно обнаружить и общую для Серля и Гуссерля озабоченность относительно сознания, которая заключается в стремлении критиковать любые формы психологизма относительно опыта, которые в современной аналитической эпистемологии объединены категорией «экстернализм». Если выразиться более кратко: мы видим и в Гуссерле, и в Серле убежденных противников «экстернализма», в том числе и относительно социальных феноменов. Что значит «обладать сознанием» по Серлю? Это, прежде всего, обладать не только сознанием, но и самосознанием, или внутренним миром, или «внутренним феноменальным рядом». Существо, обладающее сознанием, не только действует, говорит или имеет человекообразный внешний вид; такое существо обладает внутренней жизнью, или субъективностью. Поворот к интенциональности в развитии позднего Серля - это одновременно и отказ от натуралистических теорий (типа теорий Куайна и Рорти), которые доказывали несуществование таких сущностей, как «внутренний мир» и «самость» (selfness). К примеру, в своей книге «Философия и зеркало природы» (Rorty, 1979) Рорти отстаивает антиутопический проект «личностей без умов (Антиподов)», или человекоподобных существ, лишенных осознания противоположности внешнего и внутреннего миров. Теория интенциональности Рорти бросает вызов натуралистическому экстернализму относительно сознания. Если взять эволюцию идей Серля, то ощутимо его приближение к феноменологическим воззрениям Гуссерля. И хотя, как мы уже отметили, Серль не придерживается учения о чистом Я, он понимает интенциональные акты исключительно как внутренние феномены сознания. Саму же субъективность поздний Серль понимает как форму самосознания, пребывания в своем внутреннем Я. При этом субъективность оказывается «неэлиминируемой» составляющей при рассмотрении любого ментального акта. Тем самым, хотя Серль и не является «феноменологом», его вклад в американскую 
философию сознания огромен, - ведь именно он подверг критике учение о «ложном внутреннем мире» (которое развивалось в аналитической эпистемологии со времен Райла и Куайна). Серль вместе с некоторыми единомышленниками (Х. Патнэм, Ф. Анкерсмит, Э. Томпсон, Ф. Дретске, Дж. Мак-Дауэлл и др.) «возвращает» в аналитическую философию учение о самости как субъекте, наделенном не только сознанием, языком и практикой, но и самосознанием. По Серлю, Я обретает себя не в природе, не в языке, не в дискурсе, а исключительно в себе самом. Фактически Серль отстаивает позицию невозможности редукиии интенциональных актов к чему-либо за пределами внутреннего мира сознания.

Рассмотрев теорию субъективности, обратимся теперь к теории интерсубъективности, которая стремится объяснить возможность не только понимания, но и взаимопонимания, диалога и общности концептуального содержания. Гуссерль считает, что для феноменологии является значимым не только понимание индивидуального сознания, но и коммуникация между носителями сознаний, или понимание Другого. Схожая проблема присутствует и в американской философии сознания, которая называется «проблемой чужого сознания» (Other mind problem). Не вдаваясь в детали, отметим, что Гуссерль и Серль решают проблему другого сознания удивительно схоже: для обоих мыслителей Другой - это иное Я, alter Ego, которое понимается как личность, то есть наделенный самосознанием интенциональный субъект. Предметом внимания к Другому должны быть не только поступки, слова и прочие чувственно наблюдаемые проявления, но именно сознание Другого, понимаемое, как внутренний мир. Серль справедливо отмечает, что вполне можно имитировать такие внешние проявления человеческого поведения, как язык, движения членов тела, даже эмоциональные реакции. Интенционально окрашенные акты имитировать невозможно, поскольку они исходят из сферы сознания суверенной личности.

Поэтому единственно плодотворным путем понимания другого сознания и Гуссерль, и Серль считают путь установления аналогий в мышлении каждого индивидуально субъекта; и совокупность этих аналогий позволяет редуцировать человеческие сознания к сфере интерсубъективности, когда между мыслями, интенциями, поступками, мотивами и т.п. устанавливается существенное подобие. Д. В. Смит, на наш взгляд, верно отмечает, что невозможность проникнуть во внутренний мир другого субъекта вовсе не означает того, что этот мир не схож и подобен нашему миру; а это позволяет уста- 
новить такую сферу, где все люди понимают друг друга на основе похожести друг на друга.

При этом, тем не менее, не следует упрощать феноменологическое понимание интерсубъективности. Гуссерль пишет:

Другой в феноменологическом смысле есть модификация моей Самости (которая, со своей стороны, получает эту характеристику моей благодаря необходимо вступающему в действие и выявляющему контраст процессу образования пары). (Gusserl', 2010, 148)

Получается, что символический «перенос» моего Я в другое Я осуществляется по принципу als ob: как если бы я был наделен духом и плотью Другого. У нас нет возможности прямого проникновения в иное сознание; поэтому Другой представляет собой изначальную загадку. Он даже кажется нам лишь внешней оболочкой, под которой не прослеживается дух. Именно так, по Гуссерлю, смотрит на человека Юм; и этот взгляд в корне неверен. Гуссерль считает, что проблема Другого решается метафизически: каждый индивидуальный субъект подобен другому. Серль также отвергает юмистскую модель сознания, ставя во главу угла субъективность Другого (схоже смотрят на этот вопрос Ф. Дретске, Э. Томпсон и Ф. Анкерсмит); однако он видит подобие между личностями не в сходстве разумов, а в сходстве организации.

Однако, как нам кажется, на эпистемологическом уровне в рассматриваемом вопросе нет существенной разницы между Гуссерлем и Серлем. Мало того, добавим, что наблюдаемая в наши дни тенденция к отказу от юмистской эмпирической и бихевиористской психологии - это общая черта для всей философии сознания в США. О неэлиминируемой субъективности при понимании Другого ведут речь такие авторы, как Д. Деннет, С. Крипке, К. Пикок, Р. Рорти, Д. Дэвидсон, Х. Патнэм и др. Серль на фоне американских теоретиков сознания воспринимается самым «феноменологически ориентированным» исследователем сознания потому, что он не только признает ложность бихевиористской психологии, но стремится обнаружить структуры сознания, которые определяют такие качества, как «обладать субъективностью», «быть личностью», «быть наделенным интенциональностью» и т.д.

Пришло время покинуть диалогический план взаимоотношений Я и Другого и перейти к предельно широкому плану интерсубъективности вообще. Гуссерль так пишет об этом качестве: «Внутри объективного мира вместе с образованием общности в собственном, социальном смысле конституируются в качестве своеобразных духовных объективностей 
различные типы социальных общностей со свойственной им иерархией, среди них - такие особые типы общностей, которые обладают характером личностей более высокого порядка» (Gusserl', 2010, 169). Наделена ли эта социальная личность особой, коллективной интенциональностью? В. Молчанов в комментариях к переводу и русскому изданию «Картезианских медитаций» (Molchanov, 2010, 200-224), на наш взгляд, не придает этому аспекту Гуссерля существенного значения, сосредоточившись на проблеме Я и Другого. Возможно, знаток и переводчик Гуссерля верно усмотрел то, что тема коллективного сознания не получила в творчестве Гуссерля достаточного развития. В этом отношении мы предположим, что в своем учении о коллективной интенциональности (рассмотрено в разделе II) Серль не только следует Гуссерлю, но и развивает его мысли. Ведь серлевское учение о коллективной интенциональности позволяет бросить свет не только на природу человека, но и на природу «человечности» как таковой, то есть того, что можно отнести к качеству “to be a human”. Человечески ориентированная форма реализма, которую представляет Серль, возвышается до учения об особой, качественно отличной интенииональности Человечества по отночению к интенииональности отдельного человека. В этом отношении Серль в своей эволюции доходит до теории всеобщей интенциональности, в понимании которой прослеживаются определенные гегельянские черты; и это учение может позволить нам по-новому взглянуть на жизненный мир, который выступает уже не в своей «естественной данности», а в своей «изначальной сущности». Тем самым, Серль (конечно по-своему) реализует проект коллективной интенциональности, который предложен Гуссерлем в «Парижских докладах» 1929 г.: «Трансцендентальная субъективность расширяется до интерсубъективно-трансиендентальной социальности, которая является трансценденмальной почвой для интерсубъективной природь и для мира вообще, а также для интерсубъективного бытия всех идеальных предметностей» (Gusserl', 2005, 373). Наделяя «интерсубъективно-трансцендентальную социальность» собственным типом интенциональности (качественно иным, чем индивидуальная интенциональность), Серль идет дальше Гуссерля, но сохраняет преемственность с его теорией. Здесь мы хотели бы остановиться и не делать спекулятивных выводов хотя бы потому, что Серль еще творит, эволюционирует, и его концепция коллективной интенциональности социального сознания еще становящаяся философская доктрина. 
В ходе проведенного исследования получены выводы и результаты, которые можно свести к трем группам:

1. Относительно общего характера феноменологических исследований в США:

- В 1950-1970-е гг. складывается традиция изучения и комментирования наследия Гуссерля и других представителей феноменологии (Чизолм, Шютц, Финдлэй и др.); издается журнал по феноменологии «Philosophy and Phenomenological Research»;

- В 1970-1980-е гг. постепенно складывается круг авторов, которые теоретически исследуют феноменологические проблемы в критическом ключе (Г. Шпигельберг, Ф. Дретске, Дж. Фодор, М. Фарбер, У. Селларс, Н. Решер, Э. Соса и др.);

- Вокруг Университета Беркли в 1970-е гг. складывается группа философов и ученых, которая получила название «Калифорнийская феноменология» (Д. Фоллесдал, Я. Хинтикка, Г. Дрейфус, Р. Макинтайр, И. Миллер, Д. Смит и др.). Начинается этап самостоятельных феноменологических исследований;

- В качестве главной концепции исследования феноменологической проблематики в США выведена теория Дж. Серля. Рассмотрена сущность и эволюция исследований проблемы интенциональности в философии Серля (в том числе, и на основе не переведенных источников). Определена сущность самой оригинальной части учения Серла об интенциональности - положений об аспектуальности (aspectuality) интенционального акта. Определено понятие «коллективная рациональность» в трудах позднего Серля. Показано, что в своей философской эволюции Серль от книги к книге становится все менее «натуралистическим» и все более «идеалистическим» теоретиком сознания, то есть движется к все более и более «чистому» пониманию сознания;

- Показано, что в начале XXI в. в США появляется целая группа авторов, которые исследуют феноменологическую проблематику (Э. Томпсон, Д. Смит и др.). Рассмотрены их идеи на основе непереведенной на русский язык литературы. В современных американских феноменологических исследованиях налицо тенденция отхода от натуралистического понимания интенциональности, свойственного Серлю, а также к контекстуальному пониманию интенциональности. Налицо новый «антинатуралистический поворот» в современной американской трактовке интенциональности; 
- Установлено сущностное сближение позиций феноменологии и аналитической философии в области проблематики философской теории сознания, которое наиболее заметно в области проблематики опыта и интенциональности;

- Установлено, что феноменологические исследования в США примыкают по своей сути к проблематике аналитической философии, прагматизма и философии сознания;

- Предложен обобщающий концепт: «феноменологически ориентированная аналитическая философия»;

- Для осуществления главной теоретической задачи статьи проведено троякое сопоставление идей Гуссерля с идеями Серля и других американских авторов. В качестве трех тем сопоставления выделены: проблема опыта, проблема интенциональности, а также проблема субъективности и интерсубъективности.

2. Высказаны и обоснованы идеи относительно положений сходства между концепииями Гуссерля и Серля (а также других американских теоретиков феноменологической проблематики):

- Серль, Томпсон, Смит, Дретске и другие теоретики феноменологии, на наш взгляд, полностью отказались эмпирической веры в то, что акты опыта могут отражать физические объекты в их наличной данности, то есть подвергли критике идеи сенсуализма и теории чувственных данных. Это позволяет установить общность с идеей критики естественной установки Гуссерля;

- Сделана попытка доказать следующее положение: теория опыта Серля значительно ближе к теории феноменологической редукиии Гуссерля, нежели к теории чувственных данных Мура. Из чего следует, что Серль «выпадает» из аналитической традиции и движется в сторону традиции феноменологической;

- Гуссерль и Серль видят в чувственности лишь основу, которая существенна с натуралистической точки зрения, но не играет значительной роли с точки зрения гносеологической;

- Установлено, что Серль близок к феноменологии потому, что он приходит к феноменологической точке зрения о неотделимости акта опыта и редукиии содержания этого акта к сфере сознания. Человеческий опыт, по Серлю, совершенно теряет свою «физическую», «естественную» сущность, обретая взамен иную символическую, эйдетическую сущность, где правит уже не чувственность, а «аспектуальность»; 
- Гуссерль и Серль одинаково понимают природу интенциональности как преобразующей предмет восприятия сознательной деятельности вообще. Также Гуссерль и Серль стремятся обосновать естественность интенциональности как психического феномена, отнесение ее к внутренней сфере сознания;

- Для Гуссерля и Серля интенциональность суть неэлиминируемое свойство сознания;

- По Серлю, любой акт восприятия помещен в определенную «перспекmиву» (prospect), которая задается выбором «аспекта». На наш взгляд, между учением Гуссерля о горизонте и учением Серля о перспективе нет существенных различий на гносеологическом уровне;

- Серль и Гуссерль критикуют принцип «экстернализма» (согласно которому опыт анализируется на основе «внешних» проявлений) в родственной манере. Оба мыслителя стремятся обосновать внутренний характер опыта;

- Выявлены два качества интенциональности, которые характерны для Гуссерля и Серля, а именно: неотбемлемость от акта восприятия и интуитивно-созериательную перспективность;

- Установлено, что Гуссерль и Серль решают проблему другого сознания удивительно схоже: для обоих мыслителей Другой - это иное Я, alter Ego, которое понимается как личность, то есть наделенный самосознанием субъект;

- В учении о коллективной интенциональности Серль доходит до теории всеобщей интенциональности человечества; и это учение может позволить по-новому взглянуть на гуссерлевский жизненный мир, который выступает уже не в своей «естественной данности», а в своей «изначальной сущности». Тем самым, Серль реализует проект интерсубъективно-трансиендентальной сочиальности, который предложен Гуссерлем в «Парижских докладах» 1929 г.

3. Высказаны и обоснованы идеи относительно положений различий между концепциями Гуссерля и Серля (а также других американских теоретиков феноменологической проблематики):

- Серль особо подчеркивает реалистический характер своей теории интенциональности, что контрастирует с гуссерлевским идеалистическим учением о cogito. Серль понимает интенциональность в прагматистском ключе, обращая внимание, прежде всего, на функиионирование интенциональности и обоснование ее места, роли в познании;

- В отношении учения о горизонте различия нарастают на онтологическом уровне, поскольку Серль, конечно, не придает регионам онтологического статуса. Перспектива для него - это, скорее, прагматистски понимае- 
мая «установка», которая обладает исторической изменчивостью, в том числе и на уровне механизмов функционирования сознания;

- Серль чужд стремлениям Гуссерля выстроить вокруг интенциональности метафизику трансцендентального субъекта;

- Различия начинают нарастать тогда, когда речь идет об определении онтологического статуса объекта восприятия; Серль не присоединяется к учению Гуссерля о чистых феноменах;

- Серль не склонен рассматривать сознание как чистую сущность. В отличие от Гуссерля, Серль стоит на позициях метафизического скептицизма относительно возможности определения «сущности» сознания;

- Серль видит подобие между личностями не в сходстве разумов, а в сходстве организаиии;

- Наконец, различие категориального аппарата Гуссерля и Серля (а также других американских теоретиков) существенно затрудняет сопоставление. Однако, следует особо отметить, что американские мыслители стремятся сблизить три языка: аналитической философии, феноменологии и неопрагматизма. Им чужда не общая установка феноменологии, а исключительность языка трансцендентальной философии.

Как видно, установленные различия, тем не менее, не препятствуют позитивному диалогу между феноменологически ориентированной аналитической философией США и европейской феноменологией, наличию существенных сходств и совпадений в решении проблем сознания, опыта, интенциональности, понимания и т.д. Завершая исследование, следует думать, прежде всего, о позитивном итоге, а именно: о сближении позиций современной аналитической философии и феноменологии. Этот процесс вовсе не завершен; ведь американские феноменологические исследования переживают подъем. Не менее перспективным выглядит и другой вопрос для будущих исследований: Не приобрела ли современная феноменология, в свою очередь, «аналитические» черты? И не является ли сближение позиций аналитиков и феноменологов процессом, который логически и исторически неизбежен?

\section{REFERENCES}

Chernavin, G. (2016). "Nerv" fenomenologicheskoy raboty i fundamentalniy akt filosofii ["Plexus" of Phenomenological Work and the Fundamental Act of Philosophy]. Logos, 26 (1), 68-73. (in Russian). 
Chisholm, R.M. (1955-1956). Sentences about Believing. Proceedings of the Aristotelian Society, 56, $125-148$.

Dennet, D.C. (1996). Kinds of Minds: Towards an Understanding of Consciousness. London: Weidenfeld \& Nicolson.

Dummett, M.A.E. (1994). Origins of Analytic Philosophy. Cambridge MA: Harvard University Press.

Findlay, J.N. (1975). Phenomenology and the Meaning of Realism. In E. Pivčević (Ed.), Phenomenology and Philosophical Understanding (143-158). Cambridge: Cambridge University Press.

Fink, O. (2016). Problemy fenomenologii Edmunda Gusserlya [The Problem of Edmund Husserl's Phenomenology]. Logos, 26 (1), 5-46. (in Russian).

Gusserl', E. (1999). Idei k chistoy fenomenologii i fenomenologicheskoy filosofii [Ideas Pertaining to a Pure Phenomenology and to a Phenomenological Philosophy]. Moscow: Intellectual Book House. (in Russian).

Gusserl', E. (2005). Izbrannye raboty [Selected Texts]. Moscow: Territory of Future. (in Russian).

Gusserl', E. (2006). Ideya fenomenologii. Pyat' lektsii [Ideas of Phenomenology. Five Lectures]. SaintPetersburg: Gumanitarian Academy. (in Russian).

Gusserl', E. (2010). Kartezianskie meditatsii [Cartesian Meditations]. Moscow: Akademical Project. (in Russian).

Gusserl', E. (2011). Logicheskie issledovania. Tom 1 [Logical Investigations. Vol. I]. Moscow: Akademical Project. (in Russian).

Herrmann, F.V. von (2000). Ponyatie fenomenologii u Khaideggera i Gusserlya [Heidegger's and Husserl's Concept of Phenomenology]. Minsk: Propilei. (in Russian).

Khakhalova, A. (2015). Retsenziya na knigu D. Zahavi "Self and Other. Exploring Subjectivity, Sympathy, and Shame" [Review of D. Zahavi's Book "Self and Other. Exploring Subjectivity, Sympathy, and Shame"]. Horizon. Studies in Phenomenology, 4 (1), 314-321. (in Russian).

Kurennoy, V. (2012) Ustarevshaya kritika fenomenologii: po tu storonu "beskonechnogo rasputyvaniya soznaniya" [An Obsolete Critique of Phenomenology: Beyond "the Infinite Disentanglement of Consciousness"]. Logos, 26 (1), 79-88. (in Russian).

Manster, A. (1975). Austin's Linguistic Phenomenology. In E. Pivčević (Ed.), Phenomenology and Philosophical Understanding (110-124). Cambridge: Cambridge University Press.

Merlo-Ponti, M. (1999). Fenomenologiya vospriyatiya [Phenomenology of Perception]. SaintPetersburg: Juventas, Science. (in Russian).

Molchanov, V.I. (2010). Transtsendental'nyi opyt i transtsendental'naya naivnost' v "Kartezianskikh meditatsiyakh" Edmunda Gusserlya [Transcendental Experience and Transcendental Naivety in Edmund Husserl's “Cartesian Meditations"]. In E. Gusserl', Kartezianskie meditatsii [Cartesian Meditations] (200-224). Moscow: Academical project. (in Russian).

Motroshilova, N.V. (1968). Printsipy i protivorechiya fenomenologicheskoi filosofii [Principles and Contradictions of Phenomenological Philosophy]. Moscow: Higher School. (in Russian).

Motroshilova, N.V. (2003). "Idei I" Edmunda Gusserlya kak vvedeniye v fenomenologiyu [Edmund Husserl's "Ideas I" as an Introduction to Phenomenology]. Moscow: PhenomenologyHermeneutics. (in Russian).

Patkul', A.B. (2016). Trudnosti fenomenologichekogo issledovaniya: Fink i Gusserl' [Difficulties of Phenomenological Research: Fink and Husserl]. Logos, 26 (1), 89-93. (in Russian).

Pivčević, E. (Ed.). (1975). Phenomenology and Philosophical Understanding. Cambridge: Cambridge University Press.

Prekhtl', P. (1999). Vvedenie v fenomenologiyu Gusserlya [Introduction to Husserl's Phenomenology]. Tomsk: Bagpipe. (in Russian). 
Patnem, H. (2002). Razum, istina i istoriya [Reason, Truth and History]. Moscow: Praksis. (in Russian).

Razeev, D.N. (2004). V setyakh fenomenologii. In E. Gusserl' \& D. N. Razeev, V setyakh fenomenologii. Osnovnye problemy fenomenologii [In the Phenomenological Net. Main Problems of Phenomenology]. Saint Petersburg: Saint-Petersburg University Press. (in Russian).

Rorty, R. (1979). The Philosophy and the Mirror of Nature. Princeton, N.J.: Princeton University Press.

Savin, A.O. (2015). O sushchnosti fenomenologicheskoi filosofii [On the Essence of Phenomenological Philosophy]. Horizon. Studies in Phenomenology, 4 (1), 9-37. (in Russian).

Searle, J.R. (1983). Intentionality. An Essay in the Philosophy of Mind. Cambridge: Cambridge University Press.

Searle, J.R. (2002). Consciousness and Language. Cambridge: Cambridge University Press.

Serl', D. (2002). Otkryvaya soznanie zanovo [The Rediscovery of the Mind]. Moscow: Idea-Press. (in Russian).

Serl', D. (2004). Ratsional'nost' v deistvii [Rationality in Action]. Moscow: Progress-Tradition.

Smith, D.W. (2004). Mind World: Essays in Phenomenology and Ontology. Cambridge: Cambridge University Press.

Shpigel'berg, G. (2002). Fenomenologicheskoe dvizhenie [The Phenomenological Movement]. Moscow: Logos. (in Russian).

Thompson, E. (2007). Mind in Life. Biology, Phenomenology and the Science of Mind. Cambridge, Mass., London: The Belknap Press of Harvard University Press.

Uaitkhed, A.N. (1990). Izbrannye raboty po filosofii [Selected Texts on Philosophy]. Moscow: Progress (in Russian).

Vitgenshtein, L. (1994). Filosofskiye raboty I [Philosophical Works I]. Moscow: Gnozis. (in Russian). 